\title{
Dental Microwear in Live, Wild-Trapped Alouatta palliata From Costa Rica
}

\author{
MARK F. TEAFORD AND KENNETH E. GLANDER \\ Department of Cell Biology and Anatomy, The Johns Hopkins University \\ School of Medicine, Baltimore, Maryland, 21205 (M.F.T.) and \\ Department of Biological Anthropology and Anatomy, Duke University, \\ Durham, North Carolina, 27705 (K.E.G.)
}

\begin{abstract}
KEY WORDS Scanning electron microscopy, Dental microwear, Alouatta, Tooth abrasion
\end{abstract}

\begin{abstract}
One problem with dental microwear analyses of museum material is that investigators can never be sure of the diets of the animals in question. An obvious solution to this problem is to work with live animals. Recent work with laboratory primates has shown that high resolution dental impressions can be obtained from live animals. The purpose of this study was to use similar methods to begin to document rates and patterns of dental microwear for primates in the wild.

Thirty-three Alouatta palliata were captured during the wet season at Hacienda La Pacifica near Canas, Costa Rica. Dental impressions were taken and epoxy casts of the teeth were prepared using the methods of Teaford and Oyen (1989a). Scanning electron micrographs were taken of the left mandibular second molars at magnifications of $200 \times$ and $500 \times$. Lower magnification images were used to calculate rates of wear, and higher magnification images were used to measure the size and shape of microwear features.

Results indicate that, while basic patterns of dental microwear are similar in museum samples and samples of live, wild-trapped animals of the same species, ecological differences between collection locales may lead to significant intraspecific differences in dental microwear. More importantly, rates of microwear provide the first direct evidence of differences in molar use between monkeys and humans.
\end{abstract}

Dental microwear analyses have the potential to yield new insights into dental function in extinct animals (Grine, 1986; Grine and Kay, 1988; Harmon and Rose, 1988; Puech et al., 1980, 1983; Rensberger, 1978, 1986; Rose et al., 1981; Ryan and Johanson, 1989; Solounias et al., 1988; Teaford, 1991; Teaford and Walker, 1984). However, microwear interpretations of fossil teeth are ultimately based on comparisons with modern teeth, and most analyses of modern teeth (e.g., Ryan, 1981; Teaford, 1985, 1988a; Teaford and Robinson, 1989; Ungar, 1990; Van Valkenburgh et al., 1990) have involved museum specimens where investigators can never be sure of the diets of the animals in question. The only exception involves the pioneering work of Walker et al. (1978) in which hyraxes were collected during different seasons specifically for that study.

One solution to this problem is to take high resolution dental impressions from live animals so that specific differences in diet can be related to differences in dental microwear. Unfortunately, while this may seem like an easy alternative, the plain fact is that it is an extremely difficult process involving critical decisions about anesthesia for the animals, careful cleaning and drying of the teeth, and selection of appropriate materials for the taking and casting of impressions (Teaford and Oyen, 1989a). Each of these steps has the potential to cause

Received August 7, 1990; accepted January 16, 1991 
problems with the resultant dental casts (Teaford, 1988b, 1991). Thus, it is no wonder that, until recently, all attempts to take high resolution dental impressions from live animals have been unsuccessful.

Recent work with laboratory primates has shown that, under proper conditions, high resolution dental impressions can be taken from live animals (Teaford and Oyen, 1989a). The resultant epoxy casts can be used not only for standard dental microwear analyses (Teaford, 1988a,b), but also for new analyses, as the rate at which microwear features are created can be used as an indicator of the overall rate of wear of the tooth or the rate of wear of a specific location on the tooth (Teaford and Oyen, 1989c; Teaford and Tylenda, 1991). These changes in microwear can be documented in a matter of days rather than the months or years it takes to document wear-related changes in tooth shape (e.g., Carlsson et al., 1985; Lambrechts et al., 1989; Molnar et al., 1983a,b; Roulet et al., 1980; Teaford and Oyen, 1989b). Using these daily or weekly rates of tooth wear, we now have the potential to mon-itor daily or weekly changes in tooth use-including those associated with changes in diet and those associated with growth and development.

The purpose of this project was to see if high resolution dental impressions could be taken from live, wild-trapped primates so that 1) dental microwear patterns could be compared between samples of live, wildtrapped animals and those from museum collections, and 2) rates of dental microwear could be calculated for primates in the wild.

\section{MATERIALS AND METHODS}

When one considers the logistical problems that arise in many field settings (e.g., absence of electricity or running water), it becomes clear that extreme care and planning are essential if high resolution dental impressions are to be taken from live, wildtrapped primates. The animals must not only be accessible, they also must be wellstudied, so that we can be fairly sure of the feeding and ranging habits of individual animals. Since the animals need to be anesthetized for the procedure, the dental impression sessions should probably be incorporated into a larger study so that as much information as possible is gathered. In this light, the populations of $A$. palliata, from Hacienda La Pacifica near Canas, Costa Rica seemed ideal for this study. They live in patches of tropical dry forest interspersed with pasture land. As a result, they are eminently accessible and have been studied extensively over the past 20 years (Clark et al., 1987; Clarke and Glander, 1981, 1984; Glander, 1975, 1978a,b, 1979, 1980, 1981; Moreno et al., in press). On-going work includes detailed dietary and demographic studies as well as the capturing and marking of 688 animals since 1970 . Currently, 353 of the estimated 450 howlers on the ranch are marked. Data collected from these animals include body weights and measurements, footprints, and samples of blood, urine, feces, hair, and saliva. Data are collected at a field laboratory with access to electricity and running water.

For the present study, 33 monkeys were captured during the wet season using the techniques described by Glander et al. (in press). The capture drug was Telazol (A.H. Robbins), a combination of equal parts by weight of tiletamine hydrochloride (an arylaminocycloalkanone dissociative anesthetic) and zolazepam hydrochloride (a nonphenothiazine diazepinone with tranquilizing properties).

Impression techniques were generally the same as those described by Teaford and Oyen (1989a) for laboratory primates. Thus, 10-15 minutes before impressions were taken, each animal was given a small dose of atropine, to reduce salivation and to stabilize the heart rate. Food debris was removed from the mouth by brushing the teeth with a soft toothbrush and water. Organic films on the teeth were reduced by brushing the teeth with a $0.15 \%$ solution of sodium hypochlorite, after which the teeth were rinsed for 1 minute with an oral irrigation device (Water-Pik). A portable air compressor was used to dry the teeth for from 1 to 2 minutes. Dental impressions were then taken of the left mandibular tooth row using a polysiloxane impression material (President Jet, Regular Body, Coltene). Impressions were stored in zip-lock plastic bags and carried back to Baltimore where epoxy casts were poured approximately 1 month after the impressions were taken (using Araldite 9513 resin and 2964 hardener, Ciba-Geigy). The epoxy casts were then used in scanning electron microscope (SEM) analyses.

SEM micrographs were taken at magnifications of $200 \times$ or $500 \times$ using the techniques of Teaford and Walker (1984) and Teaford and Robinson (1989). Higher magnification SEM micrographs ( 2 per individual) were used to measure the size and shape of 
microwear features on facet 9 of the mandibular second molars (Teaford, 1988a; Teaford and Robinson, 1989). All 33 individuals were used in this part of the study-17 from one social group captured along the Rio Tenorito and 16 from 3 social groups isolated from the river. Nonparametric statistics (the MannWhitney test) were used to compare dental microwear measurements from this sample with those from a museum sample of $A$. palliata collected on February 16-17, 1960 at one site in Panama. The Mann-Whitney test was also used to compare dental microwear measurements from river versus non-river groups within the Costa Rican sample.

Lower magnification micrographs were used to calculate rates of wear for the second molars of 9 individuals caught twice during the study. As in previous work with laboratory monkeys (Teaford and Oyen, 1989c), baseline and follow-up micrographs of the same enamel areas were placed under an acetate transparency and examined under a $3 \times$ magnifying ring. A grid on the transparency effectively divided each micrograph into 20 smaller units to facilitate the recognition of identical microscopic wear features in each micrograph. Each microscopic scratch and pit visible on the follow-up micrograph was counted. If a scratch or pit in the follow-up micrograph was not visible in the baseline micrograph, it was also recorded as a new feature. The number of new features in the follow-up micrograph was divided by the total number of features in the follow-up micrograph to yield a proportion of microscopic wear features created between baseline and follow up. As the time between baseline and follow-up impressions ranged from 3 to 9 days, all proportions were converted to proportions of features created in 7 days which was then used as an indicator of the rate of tooth wear (Teaford and Tylenda, 1991). ${ }^{1}$ The Wilcoxon paired-sample test was used to test for differences in rates of wear between shearing and crushing-grinding

${ }^{1}$ Previous work by Boyde and Martin (1982) has shown that high concentrations (i.e., 15-30\%) of sodium hypochlorite may attack the organic component of enamel if left on the teeth overnight. While this raises the possibility that pretreatment of teeth with dilute solutions of sodium hypochlorite might affect rates of wear, the chances of significant effects in the present study are probably extremely remote for the following reasons. First, the dilution used in this study is 2 orders of magnitude less than that used by Boyde and Martin. Second, the actual time of contact with the enamel was only a matter of seconds rather than overnight. Third, application of the solution, together with subsequent tooth wear, occurred in the presence of various salivary buffers. Finally, even if rates of wear were affected, all comparisons involve samples collected using the same protocol. facets on the second molars. The MannWhitney test was used to compare weekly rates of molar wear between the howler sample and a sample of human dental patients (Teaford and Tylenda, 1991). The latter sample consisted of 9 healthy adults (aged 20 43) with rather typical American diets (e.g., hamburgers and pizza). Each patient kept a written record of all food consumed between baseline and follow-up impressions, and the time between baseline and follow-up never exceeded 7 days.

\section{RESULTS}

As in previous studies of Alouatta (Teaford, 1988a; Teaford and Walker, 1984), the molar microwear of the Costa Rican sample was characterized by the presence of far more scratches than pits (Fig. 1). However, the percentage of pits, the width of scratches, and the number of features per micrograph were all significantly greater than in the museum sample (Table 1, Fig. 2).

Within the Costa Rican sample, there was no significant difference in molar microwear between river and non-river groups, although comparisons for certain measurements (e.g., number of features per micrograph) showed nearly significant differences $(P<.07)$ (Table 2 ).

The rates of dental microwear indicate that the wild-trapped howlers wear down their teeth significantly faster than some human dental patients (Table 2 ). In fact, the howlers are probably wearing down their teeth as fast as a previously-published sample of laboratory primates raised on a hard diet, where the only available data are for $M_{1}$ (Teaford and Oyen, 1989c) (Fig. 3). Unlike the laboratory monkeys and dental patients, however, the howlers wear-down their shearing facets faster than their crushing/ grinding facets.

\section{DISCUSSION}

None of the intraspecific variations in dental microwear measurements in the present samples interfere with comparisons between Alouatta and other species with broadly different diets (e.g., Cebus apella). However, the differences in dental microwear between the Costa Rican howlers and the museum sample of howlers from Panama reaffirm that dental microwear analyses of closely. related species, or species with similar diets, must take into account ecological differences between collection locales (Teaford and Robinson, 1989). For example, while both sam- 


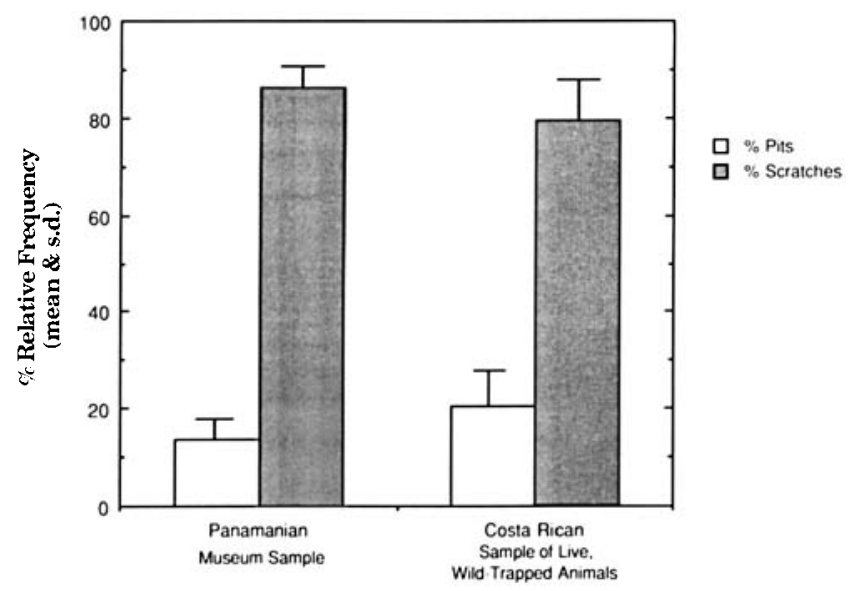

Fig. 1. Molar microwear on mandibular M2 Alouatta palliata.

TABLE 1. Descriptive statistics (mean \pm s.d.) and results of statistical comparisons of microwear measurements

\begin{tabular}{|c|c|c|c|c|}
\hline Sample & No. features/microg. & $\%$ of pits & $\begin{array}{l}\text { Scratch width } \\
\text { (in microns) }\end{array}$ & $\begin{array}{l}\text { Pit width } \\
\text { (in microns) }\end{array}$ \\
\hline $\begin{array}{l}\text { Live, wild-trapped } \\
\text { Alouatta palliata } \\
\text { from Costa Rica } \\
(\mathrm{N}=33)\end{array}$ & $147.5 \pm 47.1^{* * *}$ & $20.5 \pm 8.5^{* *}$ & $0.91 \pm .2^{*}$ & $3.28 \pm 0.8$ \\
\hline $\begin{array}{l}\text { Museum sample } \\
\text { A. palliata from } \\
\text { Panama } \\
(\mathrm{N}=14)\end{array}$ & $64.3 \pm 14.0$ & $13.8 \pm 4.7$ & $0.80 \pm .08$ & $3.59 \pm 1.1$ \\
\hline
\end{tabular}

* significantly greater than values for museum sample from Panama $(P<.05)$.

** significantly greater than values for museum sample from Panama $(P<.02)$

*** significantly greater than values for museum sample from Panama $(P<.001)$.

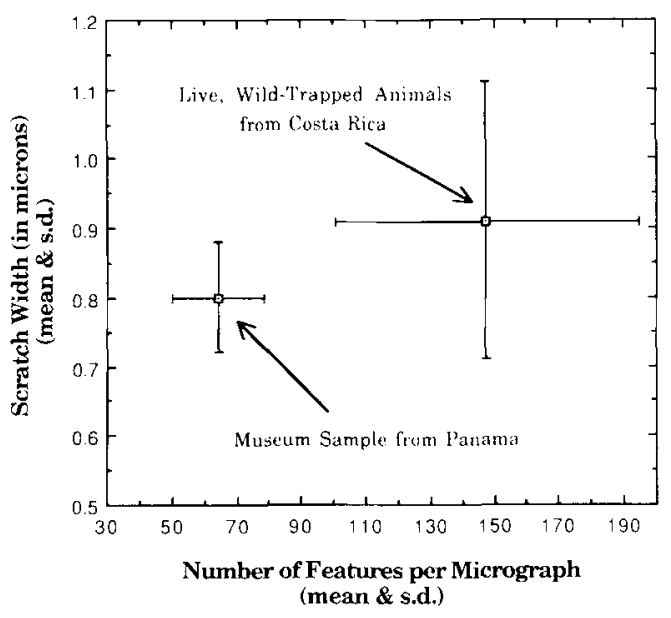

Fig. 2. Molar microwear differences between samples of Alouatta palliata. ples of Alouatta were collected during the wet season, the Costa Rican howlers were collected in a tropical dry forest, and the Panamanian howlers were collected in a tropical moist forest (Holdridge, 1971). Presumably, the Costa Rican howlers ingest more abrasives than the Panamanian howlers as evidenced by the larger number of microwear features, larger scratches, and higher incidence of pitting on their teeth. Given the marked seasonal changes in rainfall and resource availability at La Pacifica, it remains to be seen if dental microwear patterns in the Costa Rican howlers will change significantly during seasonal changes in diet. The relatively low number of features on the teeth of the Panamanian howlers suggests, once again, that either the Panamanian howlers ingest relatively few abrasives or that other wear processes, such as 
TABLE 2. Descriptive statistics (mean \pm s.d.) for microwear measurements from river and non-river groups within Costa Rican sample of Howlers

\begin{tabular}{lcccc}
\hline Group & No. features/microg. & \% of pits & $\begin{array}{c}\text { Scratch width } \\
\text { (in microns) }\end{array}$ & $\begin{array}{c}\text { Pit width } \\
\text { (in microns) }\end{array}$ \\
\hline $\begin{array}{l}\text { River group } \\
(\mathrm{N}=17)\end{array}$ & $135.1 \pm 36.8$ & $22.4 \pm 8.8$ & $0.95 \pm .17$ & $3.47 \pm 0.8$ \\
$\begin{array}{l}\text { Non-river groups } \\
(\mathrm{N}=16)\end{array}$ & $160.7 \pm 54.0$ & $18.4 \pm 8.0$ & $0.87 \pm .15$ & $3.07 \pm 0.7$ \\
\hline
\end{tabular}
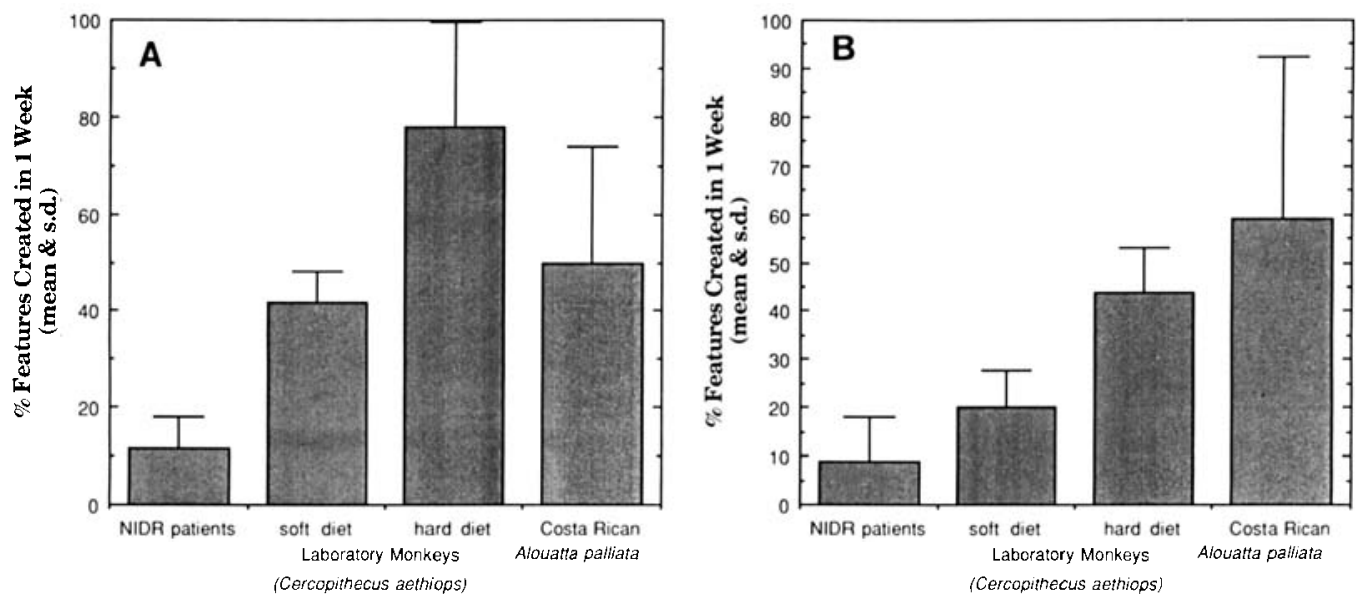

Fig. 3. A: Rates of wear on molar crushing facets. B: Rates of wear on molar shearing facets.

chemical erosion, periodically obliterate features on their teeth (Teaford, 1988a).

The rapid rates of molar wear shown by the Costa Rican howlers are perhaps not surprising given the amount of dentin exposed on their teeth. However, the fact that the Costa Rican howlers showed relatively faster wear on their molar shearing facets, whereas the laboratory monkeys and the human dental patients showed relatively faster wear on their molar crushing facets, is probably the best evidence yet in support of various theoretical discussions of primate molar use (Kay, 1975, 1977; Kay and Hiiemae, 1974; Lucas, 1979; Lucas and Luke, 1984)-i.e., the mature leaves which make up much of the diet of the Costa Rican howlers during the wet season (Glander, 1981) probably require relatively more cutting and shearing than do the prepared foods which make up most of our diet or the laboratory chow which formed most of the diet of the laboratory monkeys. This is the first direct evidence of differences in molar use between primates with different diets. Are these rates of tooth wear typical for humans and monkeys? Only further work with live primates will tell.

Taken together, the results of this study show that 1) high resolution dental impressions can be taken from live, wild-trapped primates, 2) standard dental microwear analyses of museum material must proceed cautiously in order to counter the effects of intraspecific variations in tooth use (i.e., investigators must be aware of the possible effects of differences in dental microwear associated with differences between ecological zones and seasons), and 3) new microwear features are probably created every day on the teeth of wild-trapped primates. It remains to be seen if, or how fast, dental microwear patterns (e.g., proportions of pits and scratches) change in response to changes in diet. However, one thing is certain: dental microwear analyses hold even 
TABLE 3. Rates of molar wear (\% of microwear features created in 7 days; mean \pm s.d.) ${ }^{1}$

\begin{tabular}{|c|c|c|}
\hline Sample & Crushing/grinding facets & Shearing facets \\
\hline $\begin{array}{l}\text { Human dental patients } \\
\qquad(\mathrm{N}=9)\end{array}$ & $11.8 \pm 6.2$ & $8.8 \pm 9.1$ \\
\hline $\begin{array}{l}\text { Laboratory monkeys } \\
\text { (Cercopithecus aethiops) } \\
\text { raised on a soft diet } \\
(\mathrm{N}=4)\end{array}$ & $41.7 \pm 6.5$ & $20.0 \pm 7.7$ \\
\hline $\begin{array}{l}\text { Laboratory monkeys } \\
\text { (Cercopithecus aethiops) } \\
\text { raised on a hard diet } \\
(\mathrm{N}=7)\end{array}$ & $77.9 \pm 21.5$ & $43.7 \pm 9.2$ \\
\hline $\begin{array}{l}\text { Costa Rican } \\
\text { Alouatta palliata } \\
(\mathrm{N}=9)\end{array}$ & $50.0 \pm 24.0$ & $58.9 \pm 33.5$ \\
\hline
\end{tabular}

${ }^{\prime}$ Data for humans and Alouatta are for $\mathrm{M}_{2}$. Data for laboratory monkeys are for $\mathrm{M}_{1}$ because 4 of those individuals had only recently begun using their $\mathbf{M}_{2} \mathrm{~s}$.

more potential for an even wider range of morphological and ecological research, than had previously been hoped. They can not only be used to establish a better association between microwear patterns and dietary differences; through analyses of rates of microscopic wear, they can also document how teeth are actually used in natural or laboratory environments. In other words, if weekly changes in dental microwear provide a record of weekly changes in tooth use, then dental microwear analyses can finally show us which parts of which teeth are used most frequently during the consumption of specific food items. This would provide an exciting addition to laboratory studies of feeding behavior (e.g., Hiiemae and Crompton, 1985; Hylander et al., 1987) as tooth-food-tooth movements during chewing and ingestion have traditionally proven extremely difficult to document. Finally, by reexamining the teeth of specific individuals in natural environments, investigators may even be able to document subtle changes or differences in diet (e.g., between the sexes) without nearly so much long-term, behavioral observation, as changes in dental microwear may effectively summarize 1-2 weeks of feeding differences.

\section{ACKNOWLEDGMENTS}

We thank Richard Thorington and Charles Handley (Smithsonian Institution) for allowing access to specimens in their care and for fruitful discussions during the course of this project. Fred Grine, Lawrence Martin, and 2 anonymous reviewers deserve special thanks for their useful suggestions and comments on the manuscript. We also thank
Rose Keller for her help in preparing and cataloging casts and in taking some of the SEM micrographs. This work was supported by grants from the L.S.B. Leakey Foundation, EARTHWATCH, and NSF grants $8803570,8904327,8819733$.

\section{LITERATURE CITED}

Boyde A, and Martin L (1982) Enamel microstructure determination in hominoid and cercopithecoid primates. Anat. Embryol. 165:193-212.

Carlsson GE, Johansson A, and Lundqvist S (1985) Occlusal wear: A follow-up study of 18 subjects with extensively worn dentitions. Acta Odontol. Scand. $43: 83-90$.

Clark SB, Tercyak AM, and Glander KE (1987) Plasma lipo-proteins of free-ranging howling monkeys. Comp. Biochem. Physiol. 88B:729-735.

Clarke MR, and Glander KE (1981) Adoption of infant howling monkeys (Alouatta palliata). Am. J. Primat. $1: 469-472$.

Clarke MR, and Glander KE (1984) Female reproductive success in a group of free-ranging howling monkeys (Alouatta palliata) in Costa Rica. In MF Small (ed.): Female Primates: Studies by Women Primatologists. New York: Alan R. Liss, pp. 111-126.

Glander KE (1975) Habitat description and resource utilization: A preliminary report on mantled howling monkey ecology. In RH Tuttle (ed.): Socioecology and Psychology of Primates. The Hague: Mouton, pp. 3757 .

Glander KE (1978a) Drinking from arboreal water sources by mantled howling monkeys (Alouatta palli ata Gray). Folia Primat. 29:206-217.

Glander KE (1978b) Howling monkey feeding behavior and plant secondary compounds: A study of strategies In GG Montgomery (ed.): The Ecology of Arboreal Folivores. Washington: Smithsonian Institution Press, pp. 561-573.

Glander KE (1979) Feeding associations between howling monkeys and basilisk lizards. Biotropica 11:235236.

Glander, KE (1980) Reproduction and population growth in free-ranging mantled howling monkeys. Am. J. Phys. Anthropol. 53:25-36.

Glander KE (1981) Feeding patterns in mantled howling 
monkeys. In A Kamil and TD Sargent (eds.): Foraging Behavior: Ecological, Ethological. and Psychological Approaches. New York: Garland Press, pp. 231-259.

Glander KE, Fedigan LM, Fedigan L, and Chapman C (in press) Capture techniques for three species of monkeys in Costa Rica. Folia Primat.

Grine FE (1986) Dental evidence for dietary differences in Australopithecus and Paranthropus: a quantitative analysis of permanent molar microwear. J. Hum. Evol. 15:783-822.

Grine FE, and Kay RF (1988) Early hominid diets from quantitative image analysis of dental microwear. Nature 333:765-768.

Harmon AM, and Rose JC (1988) The role of dental microwear analysis in the reconstruction of prehistoric diet. In BV Kennedy and GM Le Moine (eds.): Diet and Subsistence: Current Archaeological Perspectives. Calgary, Alberta: Archaeological Association of the Unjversity of Calgary, pp. 267-272.

Hiiemae KM, and Crompton AW (1985) Mastication, food transport, and swallowing. In $M$ Hildebrand, DM Bramble, KF Liem, and DB Wake teds.): Functional Vertebrate Morphology. Cambridge, MA: Harvard University Press, pp. 262-290.

Holdridge LR (1971) Life Zone Ecology, revised edition. San Jose: Tropical Science Center.

Hylander WL, Johnson KR, and Crompton AW (1987) Loading patterns and jaw movements during mastication in Macaca fascicularis: A bone-strain, electromyographic, and cineradiographic analysis. Am. J. Phys. Anthropol. 72:287-314

Kay RF (1975) The functional adaptations of primate molar teeth. Am. J. Phys. Anthropol. 43:195-216.

Kay RF (1977) The evolution of molar occlusion in the Cercopithecidae and early catarrhines. Am. J. Phys. Anthropol. 46:327-352.

Kay RF, and Hiiemae KM (1974) Jaw movement and tooth use in recent and fossil primates. Am. J. Phys. Anthropol. 40:227-256.

Lambrechts P, Braem M, Vuylsteke-Wauters M, and Vanherle G (1989) Quantitative in vivo wear of human enamel. J. Dent. Res. 68:1752-1759.

Lucas PW (1979) The dental-dietary adaptations of mammals. N. Jb. Geol. Palaont. Mh. 8:486-512.

Lucas PW, and Luke DA (1984) Chewing it over: Basic principles of food breakdown. In DJ Chivers, BA Wood, and A Bilsborough (eds.): Food Acquisition and Pro. cessing in Primates. New York: Plenum Press, pp. 283-301.

Molnar S, McKee JK, and Molnar I (1983a) Measurements of tooth wear among Australian Aborigines: I. Serial loss of the enamel crown. Am. J. Phys. Anthropol. 61:51-66.

Molnar S, McKee JK, Molnar IM, and Przybeck TR (1983b) Tooth-wear rates among contemporary Australian Aborigines. J. Dent. Res. 62:562-565

Moreno LI, Salas IC, and Glander KE (in press) Breech delivery and birth-related behavior in wild mantled howling monkeys. Am. J. Primat.

Puech P-F, Prone A, and Kraatz R (1980) Microscopie de l'usure dentaire chez l'homme fossile: Bol alimentaire et environnement. C.R. Acad. Sci. (Paris) $290(D)$ : $1413-1416$

Puech P-F, Albertini H, and Serratrice C (1983) Tooth microwear and dietary patterns in early hominids from Laetolil, Hadar, and Olduvai. J. Hum. Evol. 12:721-729.
Rensberger JM (1978) Scanning electron microscopy of wear and occlusal events in some small herbivores. In PM Butler and KA Joysey (eds.): Development, Function, and Evolution of Teeth. New York: Academic Press, pp. 415-438.

Rensberger JM (1986) Early chewing mechanisms in mammalian herbivores, Paleobiol. 12:474-494.

Rose KD, Walker AC, and Jacobs LL (1981) Function of the mandibular tooth comb in living and extinct mammals. Nature 289:583-585.

Roulet VJF, Mettler P, and Friedrich U (1980) Studie uber die abrasion von komposits im seitenzahnbereich-Resultate nach 3 jahren. Dtsch. Zahnarztl 35:493-497.

Ryan AS (1981) Anterior dental microwear and its relationship to diet and feeding behavior in three African primates (Pan troglodytes troglodytes, Gorilla gorilla gorilla, and Papio hamadryas). Primates 22:533-550.

Ryan AS, and Johanson DC (1989) Anterior dental microwear in Australopithecus afarensis: comparisons with human and nonhuman primates. J. Hum. Evol. 18:235-268.

Solounias N, Teaford MF, Walker A (1988) Interpreting the diet of extinct ruminants: the case of a nonbrowsing giraffid. Paleobiol 14:287-300.

Teaford MF (1985) Molar microwear and diet in the genus Cebus. Am. J. Phys. Anthropol. 66:363-370.

Teaford MF (1988a) A review of dental microwear and diet in modern mammals. Scanning Microsc 2:11491166.

Teaford MF (1988b) Scanning electron microscope diagnosis of wear patterns versus artifacts on fossil teeth. Scanning Microsc. 2:1167-1175.

Teaford MF (1991) Dental microwear: What can it tell us about diet and dental function? In MA Kelley and CS Larsen (eds): Advances in Dental Anthropology. New York: Alan R. Liss pp. 341-356.

Teaford MF, and Oyen OJ (1989a) Live primates and dental replication: new problems and new techniques. Am. J. Phys. Anthropol. 80:73-81.

Teaford MF, and Oyen OJ (1989b) Differences in the rate of molar wear between monkeys raised on different diets. J. Dent. Res. 68:1513-1518.

Teaford MF, and Oyen OJ (1989c) In vivo and in vitro turnover in dental microwear. Am. J. Phys. Anthropol. $80: 447-460$.

Teaford MF, and Robinson JG (1989) Seasonal or ecological differences in diet and molar microwear in Cebus nigrivittatus. Am. J. Phys. Anthropol. 80:391-401.

Teaford MF, and Tylenda CA (1991) A new approach to the study of tooth wear. J. Dent. Res. 70:204-207.

Teaford MF, and Walker A (1984) Quantitative differences in dental microwear between primate species with different diets and a comment on the presumed diet of Sivapithecus. Am. J. Phys. Anthropol. 64:191200.

Ungar PS (1990) Incisor use and microwear in Cebus olivaceus and Alouatta seniculus. Am. J. Primatol. 20:43-50.

Van Valkenburgh B, Teaford MF, and Walker A (1990) Molar microwear and diet in large carnivores. J. Zool. $222: 319-340$

Walker A (1981) Diet and teeth. Dietary hypotheses and human evolution. Phil. Trans. R. Soc. Lond. 292(B): $57-64$.

Walker AC, Hoeck HN, and Perez L (1978) Microwear of mammalian teeth as an indicator of diet. Science 201:908-910. 